\title{
A comparison of very short lived halocarbon (VSLS) and DMS aircraft measurements in the tropical west Pacific from CAST, ATTREX and CONTRAST
}

\author{
Stephen J. Andrews ${ }^{\mathrm{a}}$, Lucy J. Carpenter ${ }^{1}$, Eric C. Apel ${ }^{2}$, Elliot Atlas ${ }^{3}$, Valeria Donets ${ }^{3}$, James R. Hopkins ${ }^{1}$, \\ Rebecca S. Hornbrook ${ }^{2}$, Alastair C. Lewis ${ }^{1}$, Richard T. Lidster ${ }^{1}$, Richard Lueb ${ }^{2}$, Jamie Minaeian ${ }^{1}$, Maria Navarro ${ }^{3}$, \\ Shalini Punjabi ${ }^{1}$, Daniel Riemer ${ }^{3}$, and Sue Schauffler ${ }^{2}$ \\ ${ }^{1}$ Department of Chemistry, Wolfson Atmospheric Chemistry Laboratories, University of York, York, YO10 5DD, UK \\ ${ }^{2}$ National Center for Atmospheric Research, Division of Atmospheric Chemistry, Boulder, CO 80307, USA \\ ${ }^{3}$ University of Miami, Rosenstiel School for Marine \& Atmospheric Science, Miami, FL 33149, USA \\ ${ }^{a}$ Now at Center for Environmental Measurements and Analysis, National Institute for Environmental Studies, \\ 16-2 Onogawa, Tsukuba 305-8506, Japan
}

Correspondence to: Lucy J. Carpenter (lucy.carpenter@york.ac.uk)

Received: 30 March 2016 - Published in Atmos. Meas. Tech. Discuss.: 29 April 2016

Revised: 21 August 2016 - Accepted: 6 September 2016 - Published: 26 October 2016

\begin{abstract}
We present a comparison of aircraft measurements of halogenated very short lived substances (VSLSs) and dimethyl sulphide (DMS, $\mathrm{C}_{2} \mathrm{H}_{6} \mathrm{~S}$ ) from a co-ordinated campaign in January-February 2014 in the tropical west Pacific. Measurements were made on the NASA Global Hawk, NCAR Gulfstream-V High-performance Instrumented Airborne Platform for Environmental Research (GV HIAPER) and UK Facility for Airborne Atmospheric Measurements (FAAM) BAe-146 (see Sect. 2.2) using four separate gas chromatography-mass spectrometry (GC-MS) instruments: one operated by the University of Miami (UoM), one from the National Center for Atmospheric Research (NCAR) and two from the University of York (UoY). DMS was measured on the BAe-146 and GV. The instruments were intercalibrated for halocarbons during the campaign period using two gas standards on separate scales: a National Oceanic and Atmospheric Administration (NOAA) SX-3581 standard representative of clean low-hydrocarbon air, and an Essex canister prepared by UoM, representative of coastal air, which was higher in VSLS and hydrocarbon content. UoY and NCAR use the NOAA scale/standard for VSLS calibration, and UoM uses a scale based on dilutions of primary standards calibrated by GC with FID (flame ionisation detector) and AED (atomic emission detector). Analysis of the NOAA SX-3581 standard resulted in good agreement for $\mathrm{CH}_{2} \mathrm{Cl}_{2}, \mathrm{CHCl}_{3}, \mathrm{CHBr}_{3}, \mathrm{CH}_{2} \mathrm{Br}_{2}, \mathrm{CH}_{2} \mathrm{BrCl}, \mathrm{CHBrCl}$,
\end{abstract}

$\mathrm{CHBr}_{2} \mathrm{Cl}, \mathrm{CH}_{3} \mathrm{I}, \mathrm{CH}_{2} \mathrm{ICl}$ and $\mathrm{CH}_{2} \mathrm{I}_{2}$ (average relative standard deviation $(\mathrm{RSD})<10 \%$ ). Agreement was in general slightly poorer for the UoM Essex canister with an RSD of $<13 \%$. Analyses of $\mathrm{CHBrCl}_{2}$ and $\mathrm{CHBr}_{3}$ in this standard however showed significant variability, most likely due to co-eluting contaminant peaks, and a high concentration of $\mathrm{CHBr}_{3}$, respectively. These issues highlight the importance of calibration at atmospherically relevant concentrations $(\sim 0.5-5 \mathrm{ppt}$ for VSLSs; see Fig. 5 for individual ranges). The UoY in situ GC-MS measurements on board the BAe-146 compare favourably with ambient data from NCAR and UoM; however the UoY whole-air samples showed a negative bias for some lower-volatility compounds. This systematic bias could be attributed to sample line losses. Considering their large spatial variability, DMS and $\mathrm{CH}_{3} \mathrm{I}$ displayed good cross-platform agreement without any sampling bias, likely due to their higher volatility. After a correction was performed based upon the UoY in situ vs. whole-air data, all four instrument datasets show good agreement across a range of VSLSs, with combined mean absolute percentage errors (MAPEs) of the four platforms throughout the vertical profiles ranging between $2.2\left(\mathrm{CH}_{2} \mathrm{Br}_{2}\right)$ and $15\left(\mathrm{CH}_{3} \mathrm{I}\right) \%$ across a large geographic area of the tropical west Pacific. This study shows that the international VSLS calibration scales and instrumental techniques discussed here are in generally good agreement (within $\sim 10 \%$ across a range of VSLSs), but that 
losses in aircraft sampling lines can add a major source of uncertainty. Overall, the measurement uncertainty of bromocarbons during these campaigns is much less than the uncertainty in the quantity of VSLS bromine estimated to reach the stratosphere of between 2 and 8 pptv.

\section{Introduction}

Halogenated very short lived substances (VSLSs) are defined as having atmospheric lifetimes shorter than tropospheric transport timescales, i.e. of around 6 months. VSLSs (and their degradation products) are an important source of reactive halogens to the lower stratosphere (Carpenter et al., 2014; Hossaini et al., 2015). The major source of brominated (e.g. $\mathrm{CHBr}_{3}$ and $\mathrm{CH}_{2} \mathrm{Br}_{2}$ ) and iodinated (e.g. $\mathrm{CH}_{3} \mathrm{I}$ ) VSLSs is the ocean, due to production by phytoplankton (Tokarczyk and Moore, 1994; Quack and Wallace, 2003); macro algae (Carpenter and Liss, 2000; Carpenter et al., 2000; Chance et al., 2009; Goodwin et al., 1997; Leedham et al., 2013; Schall et al., 1994; Sturges et al., 1993); bacteria and detritus (Asare et al., 2012; Hughes et al., 2008); and, for $\mathrm{CH}_{3} \mathrm{I}$, photochemically (Happell and Wallace, 1996; Richter and Wallace, 2004). However, major uncertainties exist regarding the relative contribution of individual sources (Carpenter and Liss, 2000). Global distributions and controls of VSLS emissions are also not well known, exacerbated by large spatial variability in sea-air fluxes (Carpenter et al., 2005; Archer et al., 2007; Ziska et al., 2013; Stemmler et al., 2013; Orlikowska and Schulz-Bull, 2009). These are important considerations as deep convection in the tropics can rapidly transport VSLSs to the upper tropospherelower stratosphere (UTLS) and make a significant contribution to photochemical ozone depletion (Von Glasow et al., 2004; Salawitch et al., 2005; Yang et al., 2005; Montzka et al., 2011; Saiz-Lopez et al., 2012; Feng et al., 2007; Laube et al., 2008; Sinnhuber and Meul, 2015). Due to deep convection, the tropical west Pacific supplies the largest source of stratospheric air (Fueglistaler et al., 2004; Bergman et al., 2012). VSLSs are currently estimated to contribute 28 ppt of bromine to the stratosphere (Carpenter et al., 2014). Dimethyl sulfide (DMS) is also produced biogenically in the ocean and is the largest source of organic sulfur to the marine boundary layer (Cline and Bates, 1983; Nguyen et al., 1983; Andreae, 1986; Ferek et al., 1986). It affects the Earth's radiation budget and climate as an important aerosol and cloud condensation nuclei precursor.

Numerous global atmospheric transport models now include the VSLSs $\mathrm{CHBr}_{3}$ and $\mathrm{CH}_{2} \mathrm{Br}_{2}$ (Hossaini et al., 2016), driven by one of three ocean emission inventories by Liang et al. (2010), Ordóñez et al. (2012) or Ziska et al. (2013). Based on few measurements from limited geographical areas, these inventories are poorly constrained (Ashfold et al.,
2014) and contribute significantly to model uncertainties (Hossaini et al., 2013).

The Liang et al. (2010) and Ordóñez et al. (2012) topdown inventories use simple latitudinal bands to define emissions, with equatorial and coastal enhancements informed by measurements. Major effort has been made to combine ocean and atmospheric VSLS datasets and provide a bottomup (seawater-based) emission inventory (Ziska et al., 2013). For $\mathrm{CHBr}_{3}$, the Ziska inventory results in the lowest mean absolute percentage error (MAPE) between the forecast and the measurements, compared to the other inventories (Hossaini et al., 2016). However for $\mathrm{CH}_{2} \mathrm{Br}_{2}$, the Ziska et al. (2013) inventory tends to produce model overestimation of atmospheric mixing ratios, while Liang et al. (2010), with the lowest emission flux, performs favourably (Hossaini et al., 2016). One reason for poorer performance of the Ziska et al. (2013) inventory for $\mathrm{CH}_{2} \mathrm{Br}_{2}$ could be errors associated with measurements and variability between the compiled datasets, likely due to the lack of a common VSLS calibration scale.

Hossaini et al. (2016) observed that, within the 12 models they compared for the Atmospheric Tracer Transport Model Intercomparison Project (TransCom-VSLS), no single emission inventory was able to provide the best agreement between model and measurement at all surface observation comparison locations.

In order for emissions inventories based upon collated measurement datasets to provide an accurate representation of surface VSLS distribution, it is imperative that datasets be properly inter-calibrated and compared such that their errors and variability are well characterised.

\section{Experimental}

\subsection{Overview of campaigns}

The dataset inter-comparison consisted of three aircraftbased campaigns: Co-ordinated Airborne Studies in the Tropics (CAST; Harris et al., 2016), CONvective Transport of Active Species in the Tropics (CONTRAST; Pan et al., 2016) and Airborne Tropical TRopopause Experiment (ATTREX). All three campaigns were carried out in the tropical west Pacific in January-February 2014 and centred around the island of Guam $\left(13.5^{\circ} \mathrm{N}, 144.8^{\circ} \mathrm{E}\right)$. No side-by-side comparison flights were carried out, so we compare measurements on a statistical basis across a large geographic area of the west tropical Pacific where all four instruments sampled (130-165 $5^{\circ}$ E, $0-15^{\circ} \mathrm{N}$, Fig. 1, dashed purple boxes). The comparison region was limited to an altitude of $8 \mathrm{~km}$, the ceiling for the BAe-146 data. A total of 1725 data points (158 AWAS, 490 TOGA, 629 WAS and 458 in situ GCMS) were sampled within this comparison region.

The comparison region contained predominantly openocean, well-mixed air masses, with some coastal input. Elevated surface levels of VSLSs, including $\mathrm{CHBr}_{3}$, were ob- 

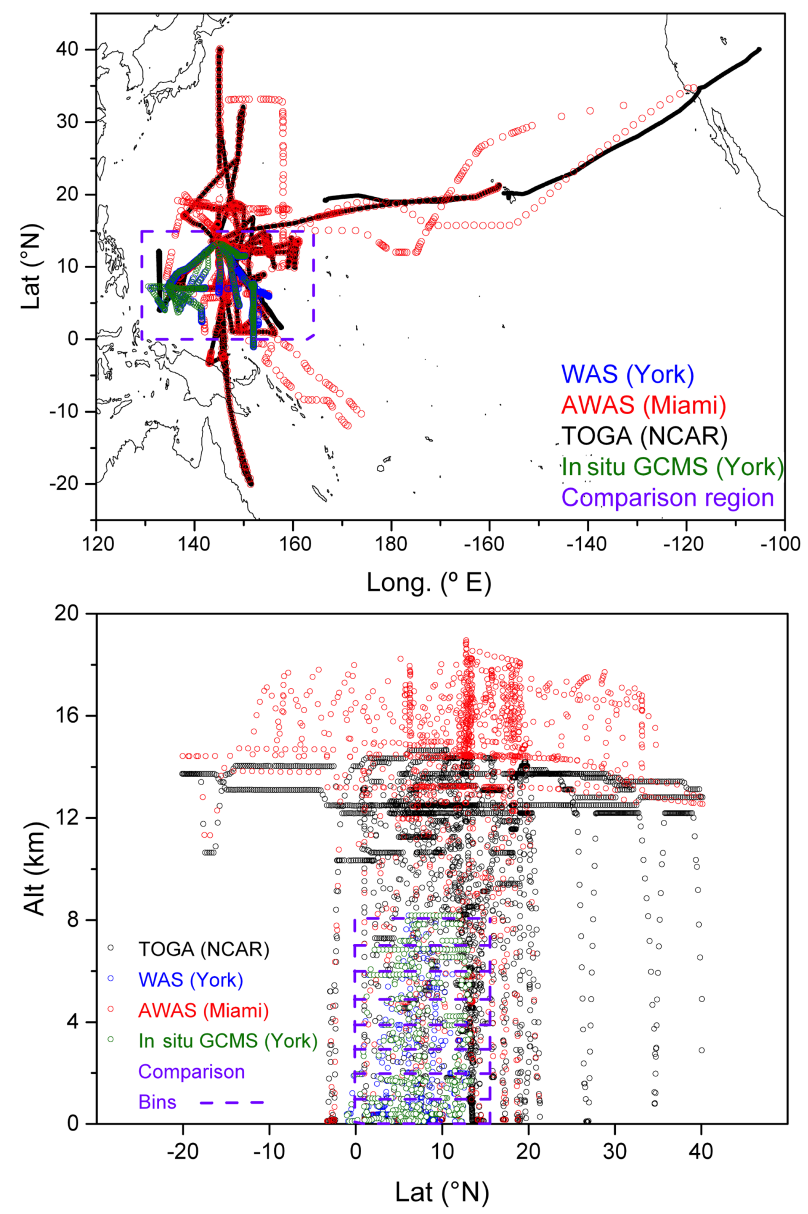

Figure 1. Top: spatial distribution of all CAST, CONTRAST and ATTREX VSLS measurements, coloured according to instrument: WAS (blue), AWAS (red), TOGA (black) and in situ GCMS (green). Box (purple dashes) depicts region chosen for sample inter-comparison. Bottom: vertical distribution of all CAST, CONTRAST and ATTREX VSLS measurements, coloured according to instrument as per Fig. 1. Purple dashed boxes show individual comparison bins (see Sect. 3.2).

served near to coastal areas and islands; this is discussed on a case-by-case basis. Due to the relative homogeneity of openocean VSLS emissions (e.g. Ziska et al., 2013), as shown by the relatively low variability of altitude-averaged data (see Sect. 3.2), outside of the coastal areas we consider that a statistical comparison of data provides a good analysis of measurement comparability.

\subsection{Methods}

The comparison involved four different instruments using individual calibration gas standards and analysing air samples from three separate measurement platforms. These platforms were the UK Facility for Airborne Atmospheric Measurements (FAAM) BAe-146 large research aircraft (CAST campaign), the National Science Foundation /National Center for Atmospheric Research (NSF/NCAR) Gulfstream-V High-performance Instrumented Airborne Platform for Environmental Research (GV HIAPER, CONTRAST campaign) and the National Aeronautics and Space Administration (NASA) Northrop Grumman Global Hawk (GH, ATTREX campaign). On board the FAAM BAe-146, air samples were analysed by the UoY both by an in situ gas chromatographmass spectrometer (in situ GC-MS, coloured green in figures) and offline as whole-air samples (whole-air sampler (WAS), coloured blue in figures) by a separate GC-MS. Air samples captured by the NSF/NCAR GV and the NASA Global Hawk were analysed by the UoM and hereto referred to by the collection apparatus name: Advanced Whole Air Sampler (AWAS, coloured red in figures). The fourth instrument was the NCAR in situ GC-MS on board the GV, referred to as the Trace Organic Gas Analyzer (TOGA, coloured black in figures). See Table 1 for a summary.

\subsubsection{Whole-air sampler (WAS)}

Samples were collected as described in Andrews et al. (2013) using evacuated $3 \mathrm{~L}$ SilcoCan canisters (Restek) sealed by pneumatically operated bellows valves (Swagelok, P/N SSBNVVCR4-C). Air was drawn in through a forward-facing air sampling pipe on the exterior of the aircraft and pressurised into the canisters using a metal bellows pump (Senior Aerospace PWSC 28823-7) to approximately $275 \mathrm{kPag}$ (40 psig). The FAAM BAe-146 has a much lower operating ceiling than the other aircraft but can profile down to $\sim 15 \mathrm{~m}$ above sea level (a.s.1.) and sampled frequently in the marine boundary layer. Due to operating at tropical latitudes, this resulted in much higher than usually experienced humidity in the sample lines, pump and canisters. Analysis of the cylinders was carried out in the aircraft hangar, usually within $72 \mathrm{~h}$ of collection. The stability of the measured VSLSs in the WAS canisters was quantified over the course of 1 month, and drift was found to be $<-0.01 \mathrm{ppt}$ per $24 \mathrm{~h}$ for all species (Andrews et al., 2013). The positive pressure in the canisters was utilised for sample introduction into the instrument to avoid contamination from any potential leaks associated with reduced pressure sampling using a pump. Sample humidity was controlled using a $-30^{\circ} \mathrm{C}$ glass cold trap to remove water without loss of the analytes (Andrews et al., 2015; Swan et al., 2015). Two litres of sample was preconcentrated onto the cooled $\left(-30^{\circ} \mathrm{C}\right)$ adsorbent trap (Tenax TA) of a thermal desorption unit (TDU, Markes UNITY 2CIA-T) and desorbed with a $2 \mathrm{~mL} \mathrm{~min}^{-1}$ helium carrier at $250{ }^{\circ} \mathrm{C}$ onto a capillary column (Restek RTX502.2, $30 \mathrm{~m}$, $0.25 \mathrm{~mm}$ I.D., $1.4 \mu \mathrm{m}$ film thickness) of a gas chromatograph (Agilent 7890A) held at $40^{\circ} \mathrm{C}$ for $3 \mathrm{~min}$ and then ramped at $25^{\circ} \mathrm{C} \mathrm{min}^{-1}$ to $250^{\circ} \mathrm{C}$ and held for $3 \mathrm{~min}$. Analytes were detected using a mass selective detector (MSD, Agilent 5977 Xtr source) with 19 selected ion windows monitoring a total of 46 ions, a qualifier and quantifier per analyte. The MSD 
Table 1. Summary of measurement platforms, instruments and institutions. Colour code refers to the colour of data displayed in figures.

\begin{tabular}{llll}
\hline Measurement & Platform & Instrument/institution & Colour code \\
\hline In situ GCMS & NCAS/FAAM BAe-146 & University of York, in situ GCMS & Green \\
WAS & NCAS/FAAM BAe-146 & University of York, ground-based GCMS & Blue (orange un adjusted) \\
AWAS & NCAR GV, NASA GH & University of Miami, ground-based GCMS & Red \\
TOGA & NCAR GV & NCAR TOGA, in situ & Black \\
\hline
\end{tabular}

source and quadrupole temperatures were 250 and $200^{\circ} \mathrm{C}$, respectively. Calibration of the WAS instrument was carried out daily for VSLSs using a NOAA calibration gas standard in a electropolished stainless-steel canister (SX-3581 Essex Cryogenics) filled in October 2013 and quantified using the NOAA 2003 scale for $\mathrm{CH}_{2} \mathrm{Cl}_{2}, \mathrm{CHCl}_{3}$ and $\mathrm{CHBr}_{3}$; NOAA 2004 scale for $\mathrm{CH}_{3} \mathrm{I}$ and $\mathrm{CH}_{2} \mathrm{Br}_{2}$; and a provisional scale for $\mathrm{CH}_{2} \mathrm{BrCl}, \mathrm{CHBrCl}_{2}, \mathrm{CHBr}_{2} \mathrm{Cl}, \mathrm{CH}_{2} \mathrm{ClI}$ and $\mathrm{CH}_{2} \mathrm{I}_{2}$ - the latter based on a limited number of standards in which mole fractions have remained consistent since 2009. NOAA SX3581 contains an ambient air matrix with halocarbon concentrations enhanced to a few parts per trillion (Hall et al., 2014). For DMS, a custom standard was prepared at the University of York containing an atmospherically relevant concentration of DMS ( $\sim 17 \mathrm{ppt}$ ) diluted with nitrogen (BOC N6 grade). This was calibrated against a KRISS primary DMS standard. Halocarbon concentrations in Essex cylinders were monitored at UoY and were found to be stable for $>4$ years after production, even for species such as $\mathrm{CH}_{2} \mathrm{I}_{2}$, which is often unstable in cylinders (Andrews, 2013). UoY have purchased three NOAA calibration cylinders: SX-3570, SX-3576 and SX-3581, which all compared well to one another's quoted values $(<4 \% \mathrm{RSD})$ according to our analyses.

\subsubsection{In situ gas chromatograph-mass spectrometer}

VSLS measurements were made in-flight using a thermal desorption (TD) GC-MS system mounted in the BAe-146 cabin. Sample air was drawn from the same main sample line as for WAS and shared the same metal bellows pump within the cabin. Air was diverted from the WAS pumping system before the sample line entered the aircraft hold and dried using a multi-core counter-current Nafion drier (Perma Pure PD series). Samples were alternately pre-concentrated or analysed using dual, parallel adsorption traps (Tenax TA, Markes International TT-24/7), cooled to $0{ }^{\circ} \mathrm{C}$. Analytes were refocused at the head of the column using liquid $\mathrm{CO}_{2}$ prior to separation (10 m, $180 \mu \mathrm{m}$ I.D., $1 \mu \mathrm{m}$ film, Restek RTX502.2 column; 50 to $150^{\circ} \mathrm{C}$ at $40^{\circ} \mathrm{C} \mathrm{min}^{-1}$ ) by GC (Agilent 6850 ) and detection by electron impact MS selected ion monitoring (Agilent 5975C), calibrated pre-flight against the WAS gas standard (NOAA, SX-3581). Instrument temporal resolution, and associated sample integration period, was $5 \mathrm{~min}$.

\subsubsection{Advanced Whole Air Sampler}

The AWAS on the GV aircraft used custom-built electropolished stainless-steel canister modules $(1.3 \mathrm{~L})$, with 12 canisters per module connected by a welded $1 / 4 \mathrm{in} .(6.35 \mathrm{~mm})$ stainless-steel manifold. Typically, five modules (60 canisters) were collected per research flight. The canisters were sealed with pneumatically operated bellows valves (Swagelok, P/N SS-BNVVCR4-C, Swagelok, USA), and sample control was by computer command, in either an automatic or on-demand mode. The canisters were pressurised by two metal bellows dual-stage pumps (Model 28823-11, Senior Aerospace, Sharon, MA, USA), with a parallel input in the first two stages followed by serial connections in the second pump to provide final pressures of approximately $345 \mathrm{kPaa}$ (50 psia). Each module was cleaned with multiple, heated flushes of pure nitrogen, with a final addition of 25 torr of water vapour to passivate interior surfaces under dry (upper-tropospheric) conditions. The inlet was an unheated stainless-steel line connected to a HIAPER Modular Inlet (HIMIL; http://www.eol.ucar.edu/homes/dcrogers/ Instruments/Inlets/) with the sample line at $90^{\circ}$ relative to the airflow in the HIMIL. A heat exchanger was installed between the pump outlet and the sample inlet to remove bulk water from the sample flow. This inlet was the same as used on the HIPPO campaign for trace gas sampling. Sample flow through the system was dependent on altitude and ranged from about 30 to $5 \mathrm{~mL} \mathrm{~min}^{-1}$. The $\mathrm{GH} 30$ sampler consisted of modular sets of canisters of either 10, 8 or 6 cans per module. The $1.3 \mathrm{~L}$ canisters were custom-built by Entech, Inc. to include a specially bent inlet tube to accommodate the module design. Each canister is coated with a proprietary silicabased coating. The canisters were sealed with Parker Series 99 valves (P/N 099-0403-900, Parker Hannifin Corp., Hollis, NJ, USA). Sample pumps were identical to the GV arrangement, but no heat exchanger was installed on the GH. An unheated, forward-facing inlet with an exit for large particles and liquid water was installed on the underside of the GH aircraft. Sample canister preparation for the GH was the same as for the GV sampler.

Trace gas measurements from both aircraft were analysed on a single system. The system used a Markes canister interface (CIA) and a UNITY 2 system connected to an Agilent 5975 GC-MSD. The samples were dried in a $-20^{\circ} \mathrm{C}$ stainless-steel water trap, followed by a $50 \mathrm{~mm} \mathrm{sec}-$ 
tion of nafion tubing (MD-050-24-FS-2; Perma Pure, Toms River, NJ) to further dry the sample. The sample was preconcentrated on a Markes ozone precursor trap (Markes UT17O3P-2S) held at $-37^{\circ} \mathrm{C}$. Sample size was $800 \mathrm{~cm}^{3}$, with a controlled flow of $80 \mathrm{sccm}$. The sample was thermally desorbed at $300^{\circ} \mathrm{C}$ for $6 \mathrm{~min}$. The sample was split in the GC oven, with approximately two-thirds $\left(525 \mathrm{~cm}^{3}\right)$ directed to a $30 \mathrm{~m} \times 0.25 \mathrm{~mm} \times 5 \mu \mathrm{m}$ Alumina PLOT column $(\mathrm{HP}-\mathrm{AL} / \mathrm{S}$, Agilent Technologies) with a flame ionisation detector. A short $(1 \mathrm{~m})$ section of GasPro column was added to the column end to facilitate separation of HFC-143a from ethyne. The remaining flow was sent to a $20 \mathrm{~m} \times 0.2 \mathrm{~mm} \times 1.12 \mu \mathrm{m}$ DB-624 column (128-1324, Agilent Technologies). At the column exit, approximately $30 \%\left(83 \mathrm{~cm}^{3}\right)$ was split in an Agilent capillary splitter and directed to an electron capture detector. The remaining sample (about $192 \mathrm{~cm}^{3}$ ) was sent to the MSD. The oven temperature programme was $-20^{\circ} \mathrm{C}$ (3 min) to $200^{\circ} \mathrm{C}$ at $10^{\circ} \mathrm{C} \mathrm{min}^{-1}$ (hold $4 \mathrm{~min}$ ).

Calibration of the samples was done between every five samples. The calibration gas was a whole-air sample collected cryogenically at the Rosenstiel School of Marine and Atmospheric Sciences directly into an Essex $30 \mathrm{~L}$ cylinder. The calibration of the working standard was done by a series of dynamic dilutions of high concentration standards (SCOTT specialty gas) that had been previously measured by GC-AED and GC-FID using NIST standards to verify carbon and halogen responses. The method has been described in Schauffler et al. (1999).

\subsubsection{Trace Organic Gas Analyzer}

VSLS and DMS measurements were made in-flight using a three-stage pre-concentrator coupled to a GC-MS system mounted in the GV cabin. Sample air was drawn through a heated electropolished stainless-steel line by a metal bellows pump. The sampled air was not drawn through the pump, but a subsample from the main inlet line was drawn at $25 \mathrm{~mL} \mathrm{~min}^{-1}$ through a water trap $\left(-25^{\circ} \mathrm{C}\right)$ and into the enrichment trap $\left(-130^{\circ} \mathrm{C}\right)$ with a sample collection time of $35 \mathrm{~s}$. Following this, the enrichment trap was heated at $25^{\circ} \mathrm{C} \mathrm{s}^{-1}$ from -130 to $100{ }^{\circ} \mathrm{C}$, and the preconcentrated sample was transferred with helium carrier gas at $1 \mathrm{~mL} \min ^{-1}$ to the cryofocus trap which was cooled to $-130^{\circ} \mathrm{C}$. The cryofocusing trap was then heated, also at $25^{\circ} \mathrm{C} \mathrm{s}^{-1}$, from the cold set point to $+100^{\circ} \mathrm{C}$, in the presence of $1 \mathrm{~mL}$ flow of He carrier gas, thereby injecting the sample onto the custom-designed GC. The GC was fitted with a Restek MXT-624 column (ID $=0.18 \mathrm{~mm}$; length $=8 \mathrm{~m}$ ). The initial GC oven temperature of $25^{\circ} \mathrm{C}$ was held for $10 \mathrm{~s}$ followed by heating to $120^{\circ} \mathrm{C}$ at a rate of $110^{\circ} \mathrm{C} \mathrm{min}^{-1}$. The oven was then immediately cooled to prepare for the next sample. Sample processing time was $2 \mathrm{~min}$. More details can be found in Apel et al. (2003). The system was calibrated with NOAA standards SX-3515 and SX 3562 prior to deployment.

\subsubsection{MAPE calculation}

In order to compare platforms, the MAPE (\%) was calculated for each instrument at each altitude bin. This shows how much each instrument has differed from the mean concentration of all data. For example, for the WAS 0-1000 m bin,

WAS MAPE $0-1000=\frac{100 \%}{n} \sum_{\mathrm{dp}=1}^{n}\left|\frac{C_{\text {mean }}-\mathrm{CWAS}_{\mathrm{dp}}}{C_{\text {mean }}}\right|$,

where $n$ is the number of individual data points in the $1000 \mathrm{~m}$ altitude bin, $\mathrm{dp}$ is the individual instrument data point within the bin, $C_{\text {mean }}$ is the mean concentration of all instrument data within the bin and CWAS $_{\mathrm{dp}}$ is the WAS individual data point concentration within the bin.

\section{Results}

\subsection{Inter-calibration}

The two instruments analysing the WAS and AWAS canisters, plus the in situ TOGA instrument, were briefly compared via inter-calibration during the campaign. The in situ GCMS calibration was directly linked to WAS and, due to operating constraints, did not take part in the comparison. A $5 \mathrm{~L}$ SilcoCan canister (Restek), identical except for volume to those used for sampling aboard the FAAM BAe-146, was evacuated and pressurised to $275 \mathrm{kPag}$ ( $40 \mathrm{psig}$ ) from the NOAA SX-3581 cylinder used to calibrate WAS. The same canister was used routinely to transfer calibration gas to the in situ GCMS and for calibration during flights spanning multiple days. This was analysed by AWAS and TOGA within $72 \mathrm{~h}$ of filling, in the same manner as a WAS sample. The analysis was performed "blind" such that the concentrations were unknown to the analysts before providing their quantifications. A second inter-calibration gas provided by UoM was analysed by each institution. This was an Essex Cryogenics cylinder identical to NOAA SX-3581, filled cryogenically and analysed directly without decanting into a WAS canister. This sample was collected on the second-floor balcony of one of the campus buildings. Because the sample included traffic emissions as well as coastal marine emissions, the UoM cylinder contained a more complex background matrix and significantly higher $\mathrm{CHBr}_{3}$ concentration than SX-3581.

Considering the simplicity of the inter-calibration exercise, with just a few analyses from each of the two cylinders, the values reported by each institution are closely comparable (Fig. 2). The average \%RSD between institutions for all analytes was $<10 \%$ for the NOAA standard SX-3581. The average RSD for the UoM cylinder was slightly higher at $<$ $13 \%$, mainly due to discrepancies in $\mathrm{CHBr}_{3}$ and $\mathrm{CHBrCl}_{2}$. The discrepancy in $\mathrm{CHBr}_{3}$ is likely due to the higher-thanambient concentration in the UoM cylinder lying outside the 

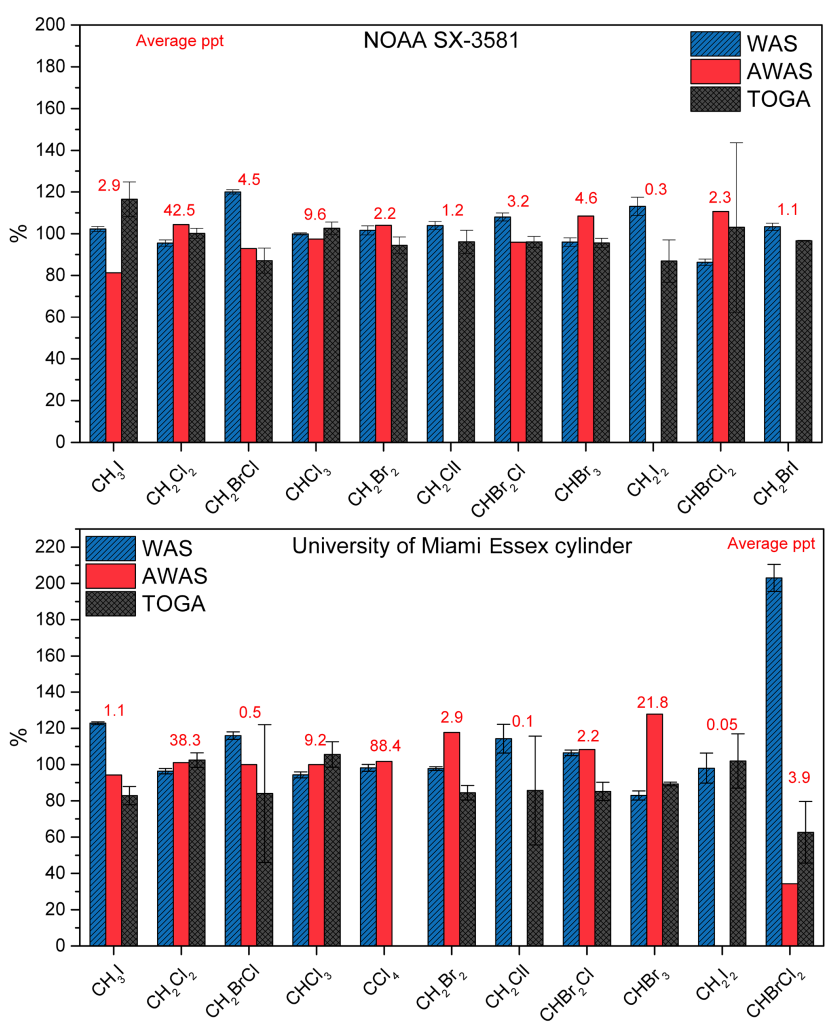

Figure 2. Inter-calibration results from the two calibration gases, shown normalised to the average for each species. Values in red denote concentrations of analytes in the respective standards; whiskers show $\pm \%$ RSD.

calibrated range of WAS and TOGA and highlights the importance of calibration at ambient concentration ranges. The error encountered in $\mathrm{CHBrCl}_{2}$ can be attributed to contamination from co-eluting chromatographic peaks. The UoY monitored ions with $m / z 127$ and 129 , which can suffer contamination issues but provide enhanced sensitivity when analysing "clean" air such as from open-ocean regions. It is likely that the TOGA instrument also suffers from contamination co-elution due to the fast chromatography employed. Air masses encountered during the CAST, CONTRAST and ATTREX campaigns were predominantly clean open ocean and more representative of the NOAA SX-3581.

\subsection{Airborne data comparison}

As the focus of the co-ordinated campaigns was to study the uplift of reactive halogens to the stratosphere, vertical profiles between platforms and instruments have been compared. This was performed by sorting the data into eight $1000 \mathrm{~m}$ altitude bins between sea level and $8 \mathrm{~km}$ pressure height, a range sampled by all three instruments. Note that the NASA Global Hawk did not sample at these altitudes, and therefore AWAS and TOGA are sampled from the same platform $(\mathrm{GV})$. We first compare $\mathrm{CHCl}_{3}$, a predominately

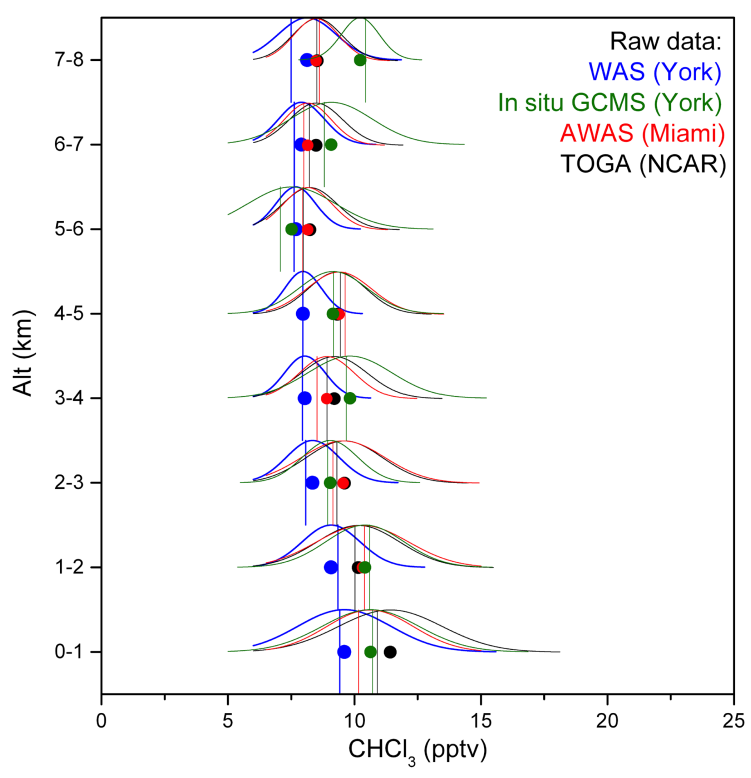

Figure 3. Comparison of unadjusted $\mathrm{CHCl}_{3}$ mixing ratios measured by all four instruments, averaged into $1000 \mathrm{~m}$ altitude bins. Circles and vertical lines are the means and medians of the binned data with the distribution represented by a normal distribution curve.

biogenic gas emitted mainly from the ocean (Laturnus et al., 2002), with a moderately high background atmospheric mixing ratio $(\sim 10 \mathrm{ppt})$ and a relatively long atmospheric lifetime (150 days; Carpenter et al., 2014). All four raw (unadjusted) $\mathrm{CHCl}_{3}$ datasets (Fig. 3) were comparable within bins to an average of $7 \% \mathrm{RSD}$. To put this in perspective, the average $\% \mathrm{RSD}$ of the $\mathrm{CHCl}_{3}$ data points within each bin is $12 \%$ for WAS, $16 \%$ for in situ GC-MS, $15 \%$ for AWAS and $25 \%$ for TOGA.

This agreement between the datasets is very good considering that these measurements were taken on different times, on different days and at different locations; from multiple sampling platforms; and using different sampling techniques. However, the York WAS data are consistently lower than the in situ GCMS, AWAS and TOGA $\mathrm{CHCl}_{3}$ data. This consistent offset is also apparent in other VSLSs, such as $\mathrm{CH}_{2} \mathrm{Br}_{2}$ (Fig. 4, bottom left), which is present at much lower concentration than $\mathrm{CHCl}_{3}$ and remains fairly constant throughout the entire profile.

Considering the profiles of all measured species, it is apparent that the UoY WAS $\mathrm{CH}_{2} \mathrm{Br}_{2}, \mathrm{CHBr}_{3}, \mathrm{CH}_{2} \mathrm{BrCl}$, $\mathrm{CHBrCl}_{2}, \mathrm{CHBr}_{2} \mathrm{Cl}, \mathrm{CH}_{2} \mathrm{Cl}_{2}$ and $\mathrm{CHCl}_{3}$ data are consistently lower $(19 \pm 1 \%$ throughout the vertical profile for $\mathrm{CH}_{2} \mathrm{Br}_{2}$ ) than the in situ GCMS, AWAS and TOGA measurements. We consider that the consistent bromo/chlorocarbon offset is not likely due to WAS sampling canister losses, which has been shown to be minimal (Andrews et al., 2013) and would likely have been seen during the inter-calibration when decanting SX-3581 into a WAS canister. One potential cause could be the sampling system aboard the FAAM 

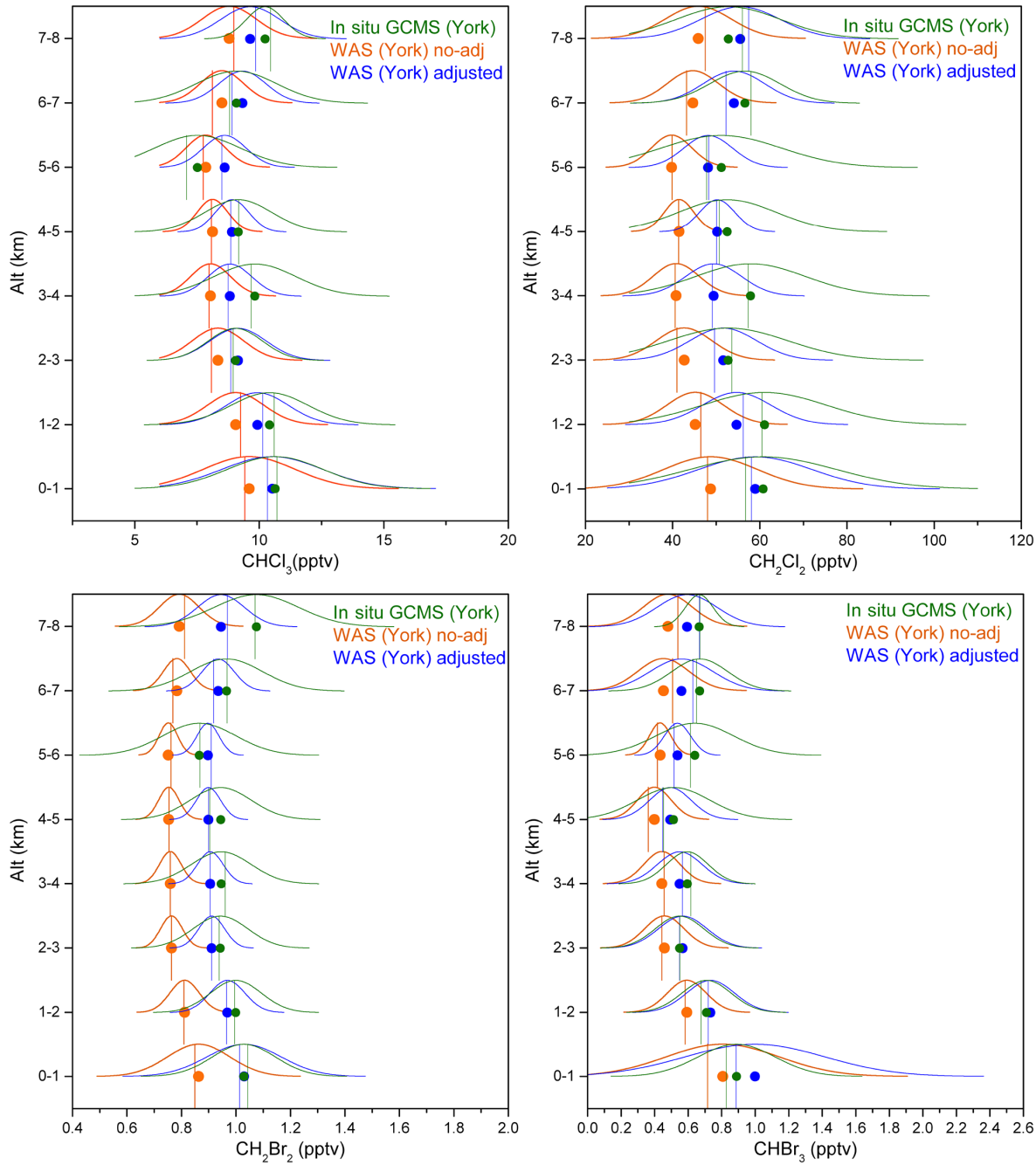

Figure 4. Vertical profile distribution bins showing a comparison of raw WAS data (orange), in situ data (green) and WAS data adjusted to in situ data via the method described in the text (blue).

BAe-146. The WAS system and in situ GCMS sample from the main science air intake, a "ram-air" type inlet that runs the length of the aircraft and exits the rear. Flow is diverted from this, through a metal bellows pump (Senior Aerospace PWSC 28823-7); the pressurised sample is supplied to the in situ GCMS and into the WAS cylinders (stored in the aircraft hold) via unheated, stainless-steel hoses; and it flows continuously whilst not sampling. Due to the high humidity and precipitation whilst operating in this region of strong convection, the WAS sampling lines often contained a large quantity of water that was removed pre-flight by pressure release from the WAS sample lines. The main inlet could not be flushed whilst stationary but was allowed to flush post-take-off before the sample pump was powered on.

In situ VSLS analysis on board the FAAM BAe-146 was performed by a GC-MS calibrated by the same method and sharing the same sample inlet and pump as for the WAS system, with the exception that the in situ GCMS sampled much closer to the outlet of the pump, before the long lines to WAS canisters in the aircraft hold where water collected preflight. The in situ GC-MS did not have the precision of the WAS samples due to the fast chromatography employed, and profiles contained a larger data spread. However, the means and medians from the altitude binned data were consistently higher than for the WAS data and agreed well with AWAS and TOGA, supporting the theory that sampling line losses caused the offset in WAS VSLS concentrations (Fig. 4). We note that, unlike the bromo/chlorocarbons, $\mathrm{CH}_{3} \mathrm{I}$ and DMS did not show a consistent offset between in situ and WAS data. This may have been due to their higher volatility and hence lower sampling losses compared to the rest of the substances analysed by UoY; these compounds also displayed a larger variability likely due to inhomogeneous ocean distributions, and therefore comparisons between datasets are not straightforward. 

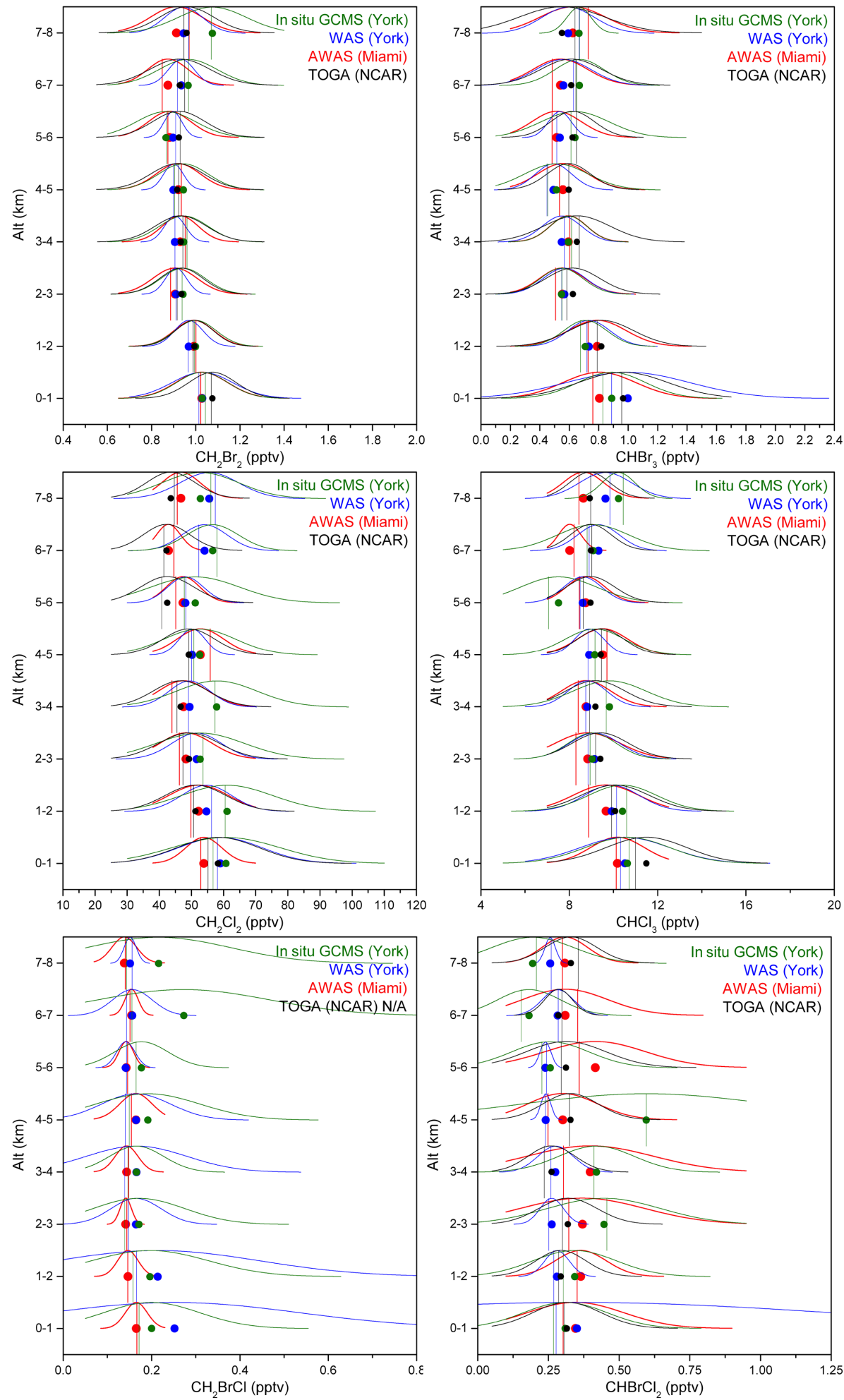

Figure 5.

The concurrent sampling of WAS and in situ GC-MS allowed a calculation of the WAS sampling offset for each affected compound. This was performed by averaging the off- set at each altitude bin where the ratio of in situ GCMS : WAS was within $1 \sigma$ of the average in situ GCMS: WAS ratio throughout the profile. This correction also improved agree- 

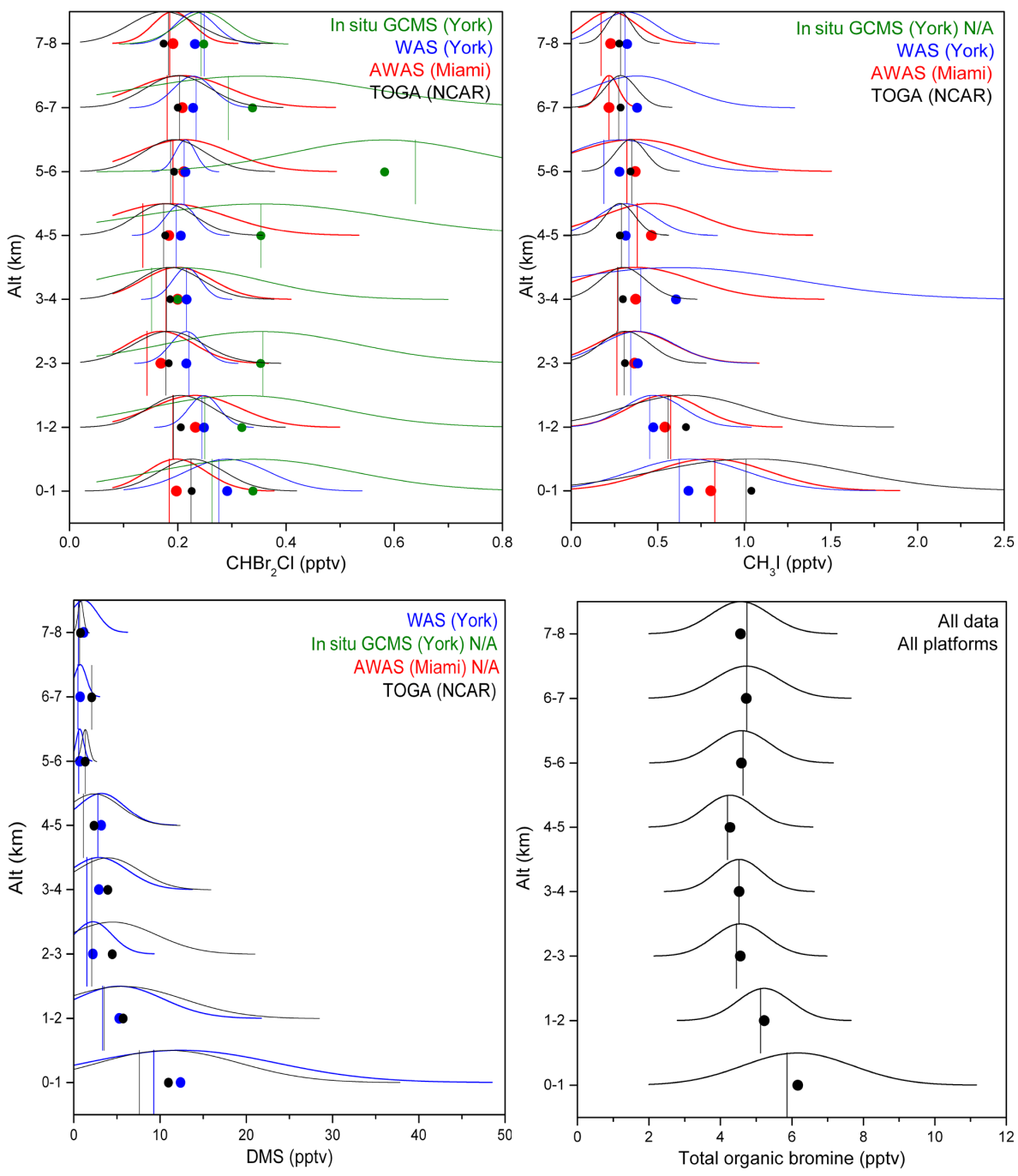

Figure 5. Vertical profile distribution bins for all species. WAS data have been adjusted as described in the text. "N/A" denotes cases where instruments have not analysed a compound. Bottom right: total organic bromine vertical profile calculated by the addition of all contributing bromine atoms from organic halocarbons, averaged across all instruments and sampling platforms.

ment of the UoY WAS data with AWAS and TOGA; for example $\mathrm{CHCl}_{3}$ improved from agreement within $7 \% \mathrm{RSD}$ across profile averages to $5 \% \mathrm{RSD}, \mathrm{CHBr}_{3}$ from $19 \%$ to $7 \%$ and $\mathrm{CH}_{2} \mathrm{Br}_{2}$ from 11 to $3 \%$.

Above $5 \mathrm{~km}$, the \%RSD for many compounds increased with increasing altitude. This can be attributed to the fact that sampling of a range of relatively fresh to highly aged air masses occurred at these altitudes. The aged air masses, possibly entrained from higher altitudes or via long-range transport, can be identified by their characteristically high $\mathrm{O}_{3}$ (Fig. 6) or low water concentrations, associated with lower VSLS concentrations. BAe-146 and GV transit flights were around 7 and $12 \mathrm{~km}$, respectively. The probability of each aircraft intercepting such air masses increases as a function of time spent at those altitudes. Removing data where $\mathrm{O}_{3}$ was greater than $50 \mathrm{ppb}$ from each dataset removes this sam- pling bias from the higher-altitude bins. All binned distribution plots here, with the exception of Fig. 3, have had the high- $\mathrm{O}_{3}$ data removed, including for the calculation of WAS offset.

In the $\mathrm{CHBr}_{3}$ data especially, samples below $1 \mathrm{~km}$ show enhanced concentrations from localised emissions such as the atoll of Chuuk (Fig. 7), Palau archipelago and Papua. WAS data showed the greatest enhancement as samples were taken from as low as $87 \mathrm{~m}$ a.s.l. and captured downwind plumes from the islands. In situ measurements such as the in situ GCMS and TOGA collect an integrated sample ( $2 \mathrm{~min}$ and $35 \mathrm{~s}$, respectively) that represents an average across the distance the aircraft has travelled in that period of about 3-6 km, whilst fill times for grab samples such as WAS and AWAS are usually around 5-10 s (altitudedependant). Therefore grab sampling can under/overestimate 

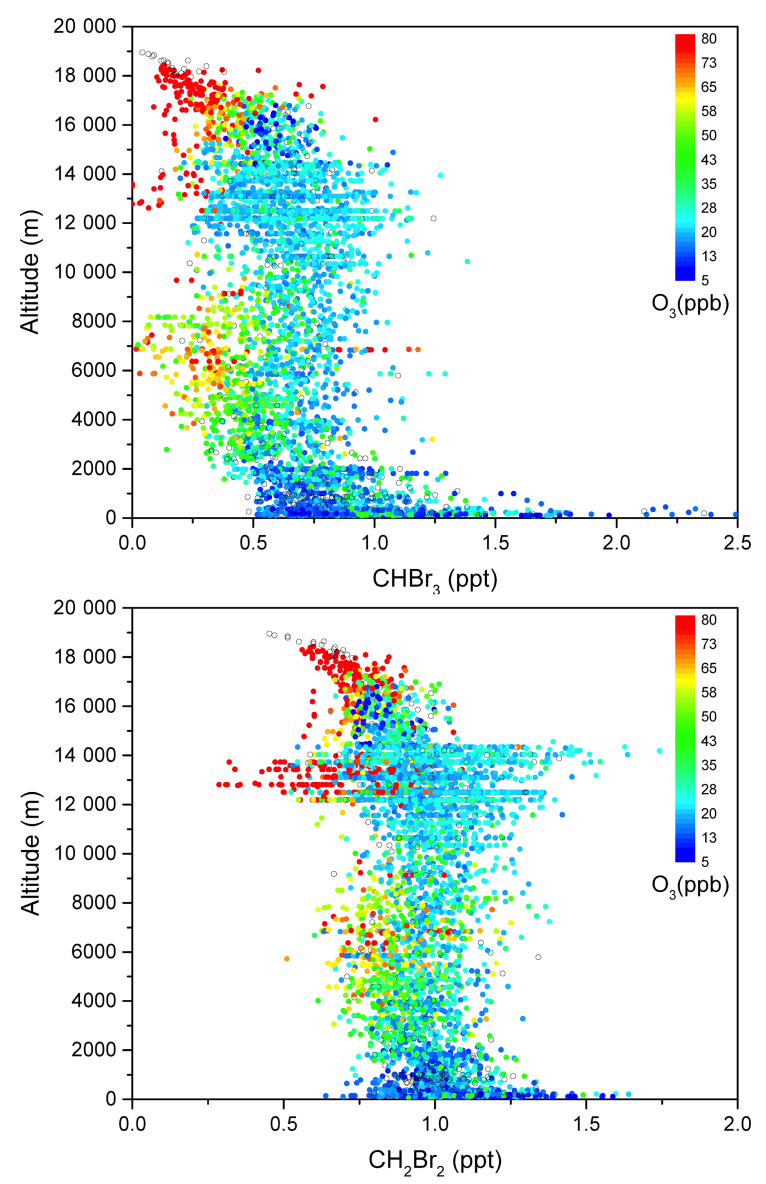

Figure 6. Vertical profiles of $\mathrm{CHBr}_{3}$ (top) and $\mathrm{CH}_{2} \mathrm{Br}_{2}$ (bottom) combined datasets, coloured by ozone concentration. Empty circles depict measurements with no corresponding ozone measurement.

average concentrations, especially at low sampling frequency, whereas in situ measurements and high-altitude grab samples will intrinsically average air masses. This could account for the difference in $\mathrm{CHBr}_{3}$ means between AWAS and TOGA and between WAS and in situ GCMS at altitudes less than $1 \mathrm{~km}$.

Combined vertical profiles for $\mathrm{CHBr}_{3}$ and $\mathrm{CH}_{2} \mathrm{Br}_{2}$, the most atmospherically abundant bromocarbons (Fig. 6), show a distinct " $C$ "-shaped profile with convective outflow visible at around $12-15000 \mathrm{~m}$. Low concentrations often coincided with enhanced $\mathrm{O}_{3}$ concentration, consistent with air masses entrained from higher altitudes. In the case of the extremely low $(<0.5 \mathrm{ppt}) \mathrm{CH}_{2} \mathrm{Br}_{2}$ measured at $\sim 13000 \mathrm{~m}$, the concentrations are lower than those measured at $18000 \mathrm{~m}$, where the ozone concentration is similar, and this may suggest sampling of different air masses from long-range transport. DMS was only quantified by WAS and TOGA and showed a highly spatially variable distribution below $2 \mathrm{~km}$, characteristic of an oceanic source that is likely inhomogeneous, such as algal growth in areas of varying nutrient distribution. Despite such spatial variability, median averages compared well between

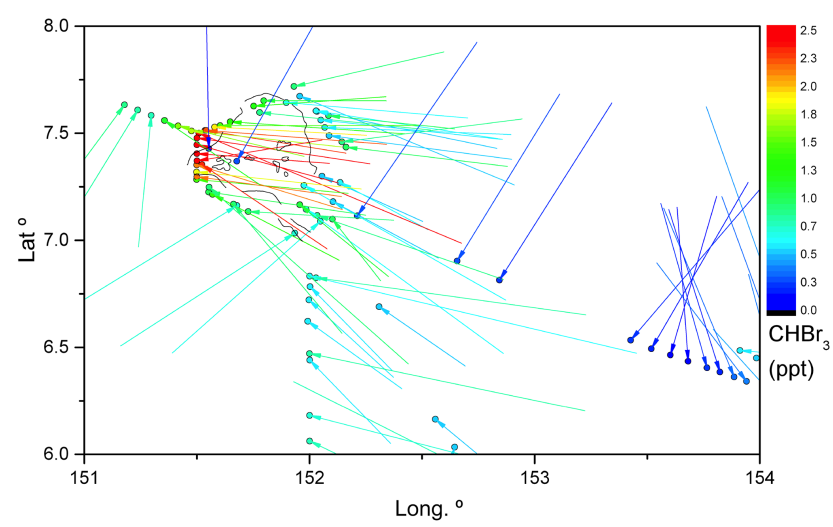

Figure 7. Localised island influence from Chuuk Atoll. Circles depict WAS sampling sites, and arrows show instantaneous wind direction and speed; both are coloured by $\mathrm{CHBr}_{3}$ concentration.

the two platforms, which each sampled with large temporal and spatial differences. This suggests that wide-scale averaging across large water bodies could give consistent results for DMS.

\subsection{Comparison of MAPE}

MAPE was calculated as described in Sect. 2.2.5; a summary of the vertical profiles of the average MAPE across all platforms, averaged across altitude bins, is shown in Table 2. The average MAPE throughout the entire vertical profile for the four different instruments discussed here (in situ GCMS, WAS, AWAS, TOGA), compared to the mean observed concentrations, was $7.7 \%$ for $\mathrm{CHBr}_{3}$ and $2.2 \%$ for $\mathrm{CH}_{2} \mathrm{Br}_{2}$. Higher MAPEs were calculated for shorter-lived species, including $\mathrm{CH}_{3} \mathrm{I}$ and DMS, where atmospheric variability is expected to make a large contribution to the spread of values measured across the different platforms.

In TransCom-VSLS, Hossaini et al. (2016) compared 12 models, using each models preferred emission inventory, with 7 recent aircraft campaigns including CAST. The model-to-measurement MAPE for all campaigns was $\leq 35 \%$ for $\mathrm{CHBr}_{3}$ and $<20 \%$ for $\mathrm{CH}_{2} \mathrm{Br}_{2}$. For most of the models studied by Hossaini et al. (2016), the model-to-groundbased observation MAPE over the latitudinal range $\pm 20^{\circ}$ was $\sim 40 \%$ for $\mathrm{CHBr}_{3}$ and $<20 \%$ for $\mathrm{CH}_{2} \mathrm{Br}_{2}$. Therefore, the differences between measurement techniques within this study are much smaller than the current differences between models and measurements.

\section{Conclusions}

We present a combined dataset of VSLS aircraft profiles in the west tropical Pacific sampled by three different research groups on board the NCAR GV and FAAM BAe146. Inter-calibration of standards showed that measurements agreed well (average RSD $<10 \%$ ) for the GC-MS 
Table 2. Summary of calculated mean absolute percentage error (MAPE) between the four instruments (two instruments in the case of $\mathrm{CH}_{2} \mathrm{BrCl}$ and DMS). Second column shows MAPE without the offset correction to WAS data applied. MAPE is shown for each altitude bin, and the average MAPE for the entire $0-8 \mathrm{~km}$ profile.

\begin{tabular}{|c|c|c|c|c|c|c|c|c|c|c|}
\hline \multirow[b]{2}{*}{ Species } & \multirow{2}{*}{$\frac{\operatorname{MAPE}(\%)}{0-8 \mathrm{~km}}$} & \multicolumn{9}{|c|}{ MAPE (\%) inc. WAS adjustment } \\
\hline & & $0-1 \mathrm{~km}$ & $1-2 \mathrm{~km}$ & $2-3 \mathrm{~km}$ & $3-4 \mathrm{~km}$ & $4-5 \mathrm{~km}$ & $5-6 \mathrm{~km}$ & $6-7 \mathrm{~km}$ & $7-8 \mathrm{~km}$ & $0-8 \mathrm{~km}$ \\
\hline $\mathrm{CHBr}_{3}$ & 9.9 & 10.5 & 9.7 & 7.3 & 4.0 & 8.6 & 7.0 & 6.8 & 7.6 & 7.7 \\
\hline $\mathrm{CH}_{2} \mathrm{Br}_{2}$ & 5.1 & 3.1 & 2.4 & 1.6 & 1.0 & 2.3 & 2.8 & 1.6 & 2.5 & 2.2 \\
\hline $\mathrm{CHCl}_{3}$ & 3.7 & 4.4 & 2.3 & 1.6 & 3.4 & 3.6 & 2.0 & 5.2 & 3.4 & 3.2 \\
\hline $\mathrm{CH}_{2} \mathrm{Cl}_{2}$ & 5.1 & 4.2 & 3.0 & 2.9 & 8.0 & 4.2 & 1.4 & 7.3 & 7.5 & 4.8 \\
\hline $\mathrm{CH}_{2} \mathrm{BrCl}$ & 10.0 & 2.5 & 0.2 & 7.4 & 11.7 & 12.1 & 12.6 & 12.0 & 9.4 & 8.5 \\
\hline $\mathrm{CHBrCl}_{2}$ & 19.2 & 6.9 & 14.2 & 16.4 & 19.8 & 11.8 & 22.2 & 8.4 & 8.5 & 13.6 \\
\hline $\mathrm{CHBr}_{2} \mathrm{Cl}$ & 11.0 & 3.2 & 13.1 & 7.4 & 9.6 & 12.8 & 14.1 & 11.4 & 10.9 & 10.3 \\
\hline $\mathrm{CH}_{3} \mathrm{I}$ & 15.0 & 15.6 & 22.3 & 7.1 & 18.5 & 19.4 & 17.0 & 13.2 & 6.6 & 15.0 \\
\hline DMS & 29.5 & 21.4 & 4.7 & 30.0 & 21.4 & 20.1 & 49.3 & 23.3 & 65.6 & 29.5 \\
\hline
\end{tabular}

analysis of $\mathrm{CH}_{2} \mathrm{Cl}_{2}, \mathrm{CHCl}_{3}, \mathrm{CHBr}_{3}, \mathrm{CH}_{2} \mathrm{Br}_{2}, \mathrm{CH}_{2} \mathrm{BrCl}$, $\mathrm{CHBrCl}_{2}, \mathrm{CHBr}_{2} \mathrm{Cl}, \mathrm{CH}_{3} \mathrm{I}, \mathrm{CH}_{2} \mathrm{ICl}$ and $\mathrm{CH}_{2} \mathrm{I}_{2}$ in a NOAA SX-3581 standard containing ambient VSLS levels. Intercalibration using an in-house standard cylinder containing super-ambient VSLS levels and contaminant peaks showed less good agreement for some compounds.

Comparison of the UoY WAS and in situ GC-MS highlighted a negative bias in the WAS data which, by ruling out instrumental error and calibration scale differences via comparison and inter-calibration, we attribute to sampling losses in the BAe-146 WAS sampling lines during the campaign. A future re-design could minimise such losses by locating the WAS cylinder instrument rack close to a window blank connected with short lengths of heated, inert tubing, allowing more direct sampling, analogous to the GV TOGA inlet system.

Once the sampling losses are corrected for, agreement between averaged (by $1 \mathrm{~km}$ altitude bin) VSLS observations and the average of all (in situ GCMS, WAS, AWAS, TOGA) VSLS observations (MAPE) is very close, within $3 \%$ for $\mathrm{CH}_{2} \mathrm{Br}_{2}$. Thus, it is apparent that spatial and temporal variability spanning months in this region of the west tropical $\mathrm{Pa}$ cific is fairly low. The BAe-146 and GV never sampled the same air mass concurrently, and yet the average MAPE for $\mathrm{CHBr} 3$, usually a more spatially variable species, throughout all profiles is $\sim 7 \%$, a value similar to the average analytical uncertainty.

Our dataset is an encouraging result for global flux emission inventories as it suggests (1) relatively small analytical and scale errors across datasets and (2) low spatial and temporal variability in tropical open-ocean regions. Thus, it should be perfectly valid for data to be collated and potentially extrapolated over large spatial areas if systematic analytical biases can be eliminated. A step forward for the VSLS community would be to link their individual institutional calibration scales, both present data and historically, to one common scale, as in Hall et al. (2014). We have found
(Andrews, 2013) that the stability of even the most reactive halocarbons $\left(\mathrm{CH}_{2} \mathrm{ICl}, \mathrm{CH}_{2} \mathrm{I}_{2}\right)$ is excellent in Essex Cryogenics air sampling canisters over long timescales ( $>3$ years) when prepared using the NOAA method (Hall et al., 2014).

\section{Data availability}

The dataset used is available at the NCAS British Atmospheric Data Centre (http://catalogue.ceda.ac.uk/uuid/ affe775e8d8890a4556aec5bc4e0b45c, Smith, 2004).

Acknowledgements. We acknowledge NERC for funding (NE/J00619X/1) and would like to thank the staff at FAAM, Directflight and Avalon Aero as well as the FAAM mission scientists for their work towards the success of the FAAM aircraft deployment in Guam. We also acknowledge the support from the US National Science Foundation and NASA.

Edited by: A. Butz

Reviewed by: three anonymous referees

\section{References}

Andreae, M. O.: The Role of Air-Sea Exchange in Geochemical Cycling, chap. The Ocean as a Source of Atmospheric Sulfur Compounds, Springer Netherlands, Dordrecht, 331-362, doi:10.1007/978-94-009-4738-2_14, 1986.

Andrews, S. J., Hackenberg, S. C., and Carpenter, L. J.: Technical Note: A fully automated purge and trap GC-MS system for quantification of volatile organic compound (VOC) fluxes between the ocean and atmosphere, Ocean Sci., 11, 313-321, doi:10.5194/os11-313-2015, 2015.

Andrews, S. J.: Short-lived halocarbon species in the Oceans and Atmosphere, PhD thesis, The University of York, http://etheses. whiterose.ac.uk/id/eprint/5675, 2013.

Andrews, S. J., Jones, C. E., and Carpenter, L. J.: Aircraft measurements of very short-lived halocarbons over the tropical Atlantic Ocean, Geophys. Res. Lett., 40, 1005-1010, 2013. 
Apel, E., Hills, A., Lueb, R., Zindel, S., Eisele, S., and Riemer, D.: A fast-GC/MS system to measure $\mathrm{C}_{2}$ to $\mathrm{C}_{4}$ carbonyls and methanol aboard aircraft, J. Geophys. Res.-Atmos., 108, 8794, doi:10.1029/2002JD003199, 2003.

Archer, S. D., Goldson, L. E., Liddicoat, M. I., Cummings, D. G., and Nightingale, P. D.: Marked seasonality in the concentrations and sea-to-air flux of volatile iodocarbon compounds in the western English Channel, J. Geophys. Res., 112, C08009, doi:10.1029/2006JC003963, 2007.

Asare, N. K., Turley, C. M., Nightingale, P. D., and Nimmo, M.: Microbially-Mediated Methyl Iodide Production in Water Samples from an Estuarine System, J. Environ., 1, 75-83, 2012.

Ashfold, M. J., Harris, N. R. P., Manning, A. J., Robinson, A. D., Warwick, N. J., and Pyle, J. A.: Estimates of tropical bromoform emissions using an inversion method, Atmos. Chem. Phys., 14, 979-994, doi:10.5194/acp-14-979-2014, 2014.

Bergman, J. W., Jensen, E. J., Pfister, L., and Yang, Q.: Seasonal differences of vertical-transport efficiency in the tropical tropopause layer: On the interplay between tropical deep convection, largescale vertical ascent, and horizontal circulations, J. Geophys. Res.-Atmos., 117, D05302, doi:10.1029/2011JD016992, 2012.

Carpenter, L. J. and Liss, P. S.: On temperate sources of bromoform and other reactive organic bromine gases, J. Geophys. Res.Atmos., 105, 20539-20547, 2000.

Carpenter, L. J., Malin, G., Liss, P. S., and Kupper, F. C.: Novel biogenic iodine-containing trihalomethanes and other short-lived halocarbons in the coastal East Atlantic, Global Biogeochem. Cy., 14, 1191-1204, 2000.

Carpenter, L. J., Hopkins, J. R., Jones, C. E., Lewis, A. C., Parthipan, R., Wevill, D. J., Poissant, L., Pilote, M., and Constant, P.: Abiotic Source of Reactive Organic Halogens in the Sub-Arctic Atmosphere?, Environ. Sci. Technol., 39, 88128816, 2005.

Carpenter, L. J., Reimann, S., Burkholder, J. B., Clerbaux, C., Hall, B. D., Hossaini, R., Laube, J. C., and Yvon-Lewis, S. A.: Update on ozone-depleting substances (ODSs) and other gases of interest to the Montreal protocol, Scientific Assessment of Ozone Depletion: 2014, 2014.

Chance, R., Baker, A. R., Küpper, F. C., Hughes, C., Kloareg, B., and Malin, G.: Release and transformations of inorganic iodine by marine macroalgae, Estuar. Coast. Shelf S., 82, 406-414, 2009.

Cline, J. D. and Bates, T. S.: NOAA/Pacific Marine Environmental Laboratory, Seattle, Washington 98115, Geophys. Res. Lett., 10, 949-952, 1983.

Feng, W., Chipperfield, M. P., Davies, S., von der Gathen, P., Kyro, E., Volk, C. M., Ulanovsky, A., and Belyaev, G.: Large chemical ozone loss in 2004/2005 Arctic winter/spring, Geophys. Res. Lett., 34, L09803, doi:10.1029/2006GL029098, 2007.

Ferek, R. J., Chatfield, R. B., and Andreae, M. O.: Vertical distribution of dimethylsulphide in the marine atmosphere, Nature, 320, 514-516, doi:10.1038/320514a0, 1986.

Fueglistaler, S., Wernli, H., and Peter, T.: Tropical troposphereto-stratosphere transport inferred from trajectory calculations, J. Geophys. Res.-Atmos., 109, D03108, doi:10.1029/2003JD004069, 2004.

Goodwin, K. D., North, W. J., and Lidstrom, M. E.: Production of bromoform and dibromomethane by giant kelp: factors affecting release and comparison to anthropogenic bromine sources, Lim- nol. Oceanogr., 42, 1725-1734, doi:10.4319/lo.1997.42.8.1725, 1997.

Hall, B. D., Engel, A., Mühle, J., Elkins, J. W., Artuso, F., Atlas, E., Aydin, M., Blake, D., Brunke, E.-G., Chiavarini, S., Fraser, P. J., Happell, J., Krummel, P. B., Levin, I., Loewenstein, M., Maione, M., Montzka, S. A., O'Doherty, S., Reimann, S., Rhoderick, G., Saltzman, E. S., Scheel, H. E., Steele, L. P., Vollmer, M. K., Weiss, R. F., Worthy, D., and Yokouchi, Y.: Results from the International Halocarbons in Air Comparison Experiment (IHALACE), Atmos. Meas. Tech., 7, 469-490, doi:10.5194/amt-7469-2014, 2014.

Happell, J. D. and Wallace, D. W. R.: Methyl iodide in the Greenland/Norwegian Seas and the tropical Atlantic Ocean: Evidence for photochemical production, Geophys. Res. Lett., 23, 2105 2108, 1996.

Harris, N. R. P., Carpenter, L. J., Lee, J. D., Vaughan, G., Filus, M. T., Jones, R. L., OuYang, B., Pyle, J. A., Robinson, A. D., Andrews, S. J., Lewis, A. C., Minaeian, J., Vaughan, A., Dorsey, J. R., Gallagher, M. W., Breton, M. L., Newton, R., Percival, C. J., Ricketts, H. M. A., Baugitte, S. J.-B., Nott, G. J., Wellpott, A., Ashfold, M. J., Flemming, J., Butler, R., Palmer, P. I., Kaye, P. H., Stopford, C., Chemel, C., Boesch, H., Humpage, N., Vick, A., MacKenzie, A. R., Hyde, R., Angelov, P., Meneguz, E., and Manning, A. J.: Co-ordinated Airborne Studies in the Tropics (CAST), B. Am. Meteorol. Soc., doi:10.1175/BAMS-D-1400290.1, online first, 2016.

Hossaini, R., Mantle, H., Chipperfield, M. P., Montzka, S. A., Hamer, P., Ziska, F., Quack, B., Krüger, K., Tegtmeier, S., Atlas, E., Sala, S., Engel, A., Bönisch, H., Keber, T., Oram, D., Mills, G., Ordóñez, C., Saiz-Lopez, A., Warwick, N., Liang, Q., Feng, W., Moore, F., Miller, B. R., Marécal, V., Richards, N. A. D., Dorf, M., and Pfeilsticker, K.: Evaluating global emission inventories of biogenic bromocarbons, Atmos. Chem. Phys., 13, 11819-11838, doi:10.5194/acp-13-11819-2013, 2013.

Hossaini, R., Chipperfield, M. P., Montzka, S. A., Rap, A., Dhomse, S., and Feng, W.: Efficiency of short-lived halogens at influencing climate through depletion of stratospheric ozone, Nat. Geosci., 8, 186-190, doi:10.1038/ngeo2363, 2015.

Hossaini, R., Patra, P. K., Leeson, A. A., Krysztofiak, G., Abraham, N. L., Andrews, S. J., Archibald, A. T., Aschmann, J., Atlas, E. L., Belikov, D. A., Bönisch, H., Carpenter, L. J., Dhomse, S., Dorf, M., Engel, A., Feng, W., Fuhlbrügge, S., Griffiths, P. T., Harris, N. R. P., Hommel, R., Keber, T., Krüger, K., Lennartz, S. T., Maksyutov, S., Mantle, H., Mills, G. P., Miller, B., Montzka, S. A., Moore, F., Navarro, M. A., Oram, D. E., Pfeilsticker, K., Pyle, J. A., Quack, B., Robinson, A. D., Saikawa, E., Saiz-Lopez, A., Sala, S., Sinnhuber, B.-M., Taguchi, S., Tegtmeier, S., Lidster, R. T., Wilson, C., and Ziska, F.: A multi-model intercomparison of halogenated very short-lived substances (TransComVSLS): linking oceanic emissions and tropospheric transport for a reconciled estimate of the stratospheric source gas injection of bromine, Atmos. Chem. Phys., 16, 9163-9187, doi:10.5194/acp16-9163-2016, 2016.

Hughes, C., Malin, G., Turley, C. M., Keely, B. J., Nightingale, P. D., and Liss, P. S.: The production of volatile iodocarbons by biogenic marine aggregates, Limnol. Oceanogr., 53, 867-872, doi:10.4319/lo.2008.53.2.0867, 2008. 
Laturnus, F., Haselmann, K. F., Borch, T., and Gron, C.: Terrestrial natural sources of trichloromethane (chloroform, $\mathrm{CHCl} \mathrm{3)} \mathrm{-} \mathrm{An}$ overview, Biogeochemistry, 60, 121-139, 2002.

Laube, J. C., Engel, A., Bönisch, H., Möbius, T., Worton, D. R., Sturges, W. T., Grunow, K., and Schmidt, U.: Contribution of very short-lived organic substances to stratospheric chlorine and bromine in the tropics - a case study, Atmos. Chem. Phys., 8, 7325-7334, doi:10.5194/acp-8-7325-2008, 2008.

Leedham, E. C., Hughes, C., Keng, F. S. L., Phang, S.-M., Malin, G., and Sturges, W. T.: Emission of atmospherically significant halocarbons by naturally occurring and farmed tropical macroalgae, Biogeosciences, 10, 3615-3633, doi:10.5194/bg-10-36152013, 2013.

Liang, Q., Stolarski, R. S., Kawa, S. R., Nielsen, J. E., Douglass, A. R., Rodriguez, J. M., Blake, D. R., Atlas, E. L., and Ott, L. E.: Finding the missing stratospheric $\mathrm{Br}_{y}$ : a global modeling study of $\mathrm{CHBr}_{3}$ and $\mathrm{CH}_{2} \mathrm{Br}_{2}$, Atmos. Chem. Phys., 10, 2269-2286, doi:10.5194/acp-10-2269-2010, 2010.

Montzka, S., Reimann, S., O’Doherty, S., Engel, A., Krü, G. K., and Sturges, W. T.: Ozone-depleting substances (ODSs) and related chemicals, Scientific Assessment of Ozone Depletion: 2011, 2011.

Nguyen, B. C., Bonsang, B., and Gaudry, A.: The role of the ocean in the global atmospheric sulfur cycle, J. Geophys. Res.-Oceans, 88, 10903-10914, 1983.

Ordóñez, C., Lamarque, J.-F., Tilmes, S., Kinnison, D. E., Atlas, E. L., Blake, D. R., Sousa Santos, G., Brasseur, G., and Saiz-Lopez, A.: Bromine and iodine chemistry in a global chemistry-climate model: description and evaluation of very short-lived oceanic sources, Atmos. Chem. Phys., 12, 1423-1447, doi:10.5194/acp12-1423-2012, 2012.

Orlikowska, A. and Schulz-Bull, D. E.: Seasonal variations of volatile organic compounds in the coastal Baltic Sea, Environ. Chem., 6, 495-507, 2009.

Pan, L. L., Atlas, E. L., Salawitch, R. J., Honomichl, S. B., Bresch, J. F., Randel, W. J., Apel, E. C., Hornbrook, R. S., Weinheimer, A. J., Anderson, D. C., Andrews, S. J., Beaton, S. P., Campos, T. L., Carpenter, L. J., Chen, D., Dix, B., Donets, V., Hall, S. R., Hanisco, T. F., Homeyer, C. R., Huey, L. G., Jensen, J. B., Kaser, L., Kinnison, D. E., Koenig, T. K., Lamarque, J.-F., Liu, C., Luo, J., Luo, Z. J., Montzka, D. D., Nicely, J. M., Pierce, R. B., Riemer, D. D., Robinson, T., Romashkin, P., Saiz-Lopez, A., Schauffler, S., Shieh, O., Vaughan, G., Ullmann, K., Volkamer, R., Wolfe, G., Stell, M. H., and Baidar, S.: The CONvective TRansport of Active Species in the Tropics (CONTRAST) Experiment, B. Am. Meteorol. Soc., doi:10.1175/BAMS-D-1400272.1, online first, 2016.

Quack, B. and Wallace, D. W. R.: Air-sea flux of bromoform: Controls, rates, and implications, Global Biogeochem. Cy., 17, 1023, doi:10.1029/2002GB001890,1, 2003.

Richter, U. and Wallace, D. W. R.: Production of methyl iodide in the tropical Atlantic Ocean, Geophys. Res. Lett, 31, L23S03, doi:10.1029/2004GL020779, 2004.

Saiz-Lopez, A., Plane, J. M. C., Baker, A. R., Carpenter, L. J., von Glasow, R., Gómez Martín, J. C., McFiggans, G., and Saunders, R. W.: Atmospheric Chemistry of Iodine, Chem. Rev., 112, 1773-1804, 2012.
Salawitch, R. J., Weisenstein, D. K., Kovalenko, L. J., Sioris, C. E., Wennberg, P. O., Chance, K., Ko, M. K. W., and McLinden, C. A.: Sensitivity of ozone to bromine in the lower stratosphere, Geophys. Res. Lett., 32, L05811, doi:10.1029/2004GL021504, 2005.

Schall, C., Laturnus, F., and Heumann, K. G.: Biogenic volatile organoiodine and organobromine compounds released from polar macroalgae, Chemosphere, 28, 1315-1324, 1994.

Schauffler, S. M., Atlas, E. L., Blake, D. R., Flocke, F., Lueb, R. A., Lee-Taylor, J. M., Stroud, V., and Travnicek, W.: Distributions of brominated organic compounds in the troposphere and lower stratosphere, J. Geophys. Res., 104, 21513-21535, 1999.

Sinnhuber, B.-M. and Meul, S.: Simulating the impact of emissions of brominated very short lived substances on past stratospheric ozone trends, Geophys. Res. Lett., 42, 2449-2456, 2015.

Smith, M.: Facility for Airborne Atmospheric Measurements (FAAM) flights, Met Office, Natural Environment Research Council, NCAS British Atmospheric Data Centre, available at: http://catalogue.ceda.ac.uk/uuid/ affe775e8d8890a4556aec5bc4e0b45c, 2004.

Stemmler, I., Rothe, M., Hense, I., and Hepach, H.: Numerical modelling of methyl iodide in the eastern tropical Atlantic, Biogeosciences, 10, 4211-4225, doi:10.5194/bg-10-4211-2013, 2013.

Sturges, W. T., Sullivan, C. W., Schnell, R. C., Heidt, L. E., and Pollock, W. H.: Bromoalkane production by Antarctic ice algae, Tellus B, 45, 120-126, 1993.

Swan, H. B., Ivey, J. P., Jones, G. B., and Eyre, B. D.: The validation and measurement uncertainty of an automated gas chromatograph for marine studies of atmospheric dimethylsulfide, Anal. Method., 7, 3893-3902, 2015.

Tokarczyk, R. and Moore, R. M.: Production of volatile organohalogens by phytoplankton cultures, Geophys. Res. Lett., 21, 285288, 1994.

von Glasow, R., von Kuhlmann, R., Lawrence, M. G., Platt, U., and Crutzen, P. J.: Impact of reactive bromine chemistry in the troposphere, Atmos. Chem. Phys., 4, 2481-2497, doi:10.5194/acp-42481-2004, 2004.

Yang, X., Cox, R. A., Warwick, N. J., Pyle, J. A., Carver, G. D., O'Connor, F. M., and Savage, N. H.: Tropospheric bromine chemistry and its impacts on ozone: A model study, J. Geophys. Res., 110, D23311, doi:10.1029/2005JD006244, 2005.

Ziska, F., Quack, B., Abrahamsson, K., Archer, S. D., Atlas, E., Bell, T., Butler, J. H., Carpenter, L. J., Jones, C. E., Harris, N. R. P., Hepach, H., Heumann, K. G., Hughes, C., Kuss, J., Krüger, K., Liss, P., Moore, R. M., Orlikowska, A., Raimund, S., Reeves, C. E., Reifenhäuser, W., Robinson, A. D., Schall, C., Tanhua, T., Tegtmeier, S., Turner, S., Wang, L., Wallace, D., Williams, J., Yamamoto, H., Yvon-Lewis, S., and Yokouchi, Y.: Global sea-toair flux climatology for bromoform, dibromomethane and methyl iodide, Atmos. Chem. Phys., 13, 8915-8934, doi:10.5194/acp13-8915-2013, 2013. 